\title{
Youth Voter Political Education to Increase Rights Participation Choose in General Elections
}

\author{
Nina Angelia*, Walid Mustafa Sembiring, Taufik Wal Hidayat, Armansyah Matondang \\ Lecturer at Faculty of Politics and Social Science, University of Medan Area, Indonesia \\ *Corresponding Author: Nina Angelia, Lecturer at Faculty of Politics and Social Science, University of \\ Medan Area, Indonesia
}

\begin{abstract}
The purpose of this study was to find out the knowledge of political education for young voters in order to increase the participation of voters in general elections (Election) in the State High School 1 Percut Sei Tuan Deli Serdang Regency. The research method used is a qualitative research method. The implementation technique uses the BRIDGE pattern which is to prioritize the activity of participants / students so that they are directly involved in understanding the importance of concepts theoretically as well as applied to democracy and political representation. In addition, for young voters to understand what elections are, why do they need to take part in elections and how procedures for using voting rights in elections. After young voters understand the various issues of elections, it is expected that young voters become smart voters, namely voters who are aware of using their voting rights and can choose quality leaders to improve the future of the nation and state. The results of this study indicate that education (1) is able to increase knowledge about the value of democracy, improve the quality of the electoral process, increase participation of young voters (2) political education for young voters is very necessary in order to provide clear information about what is stated in the function elections and use of voting rights. Political education about the function of elections and voting rights for young voters must be made both verbally and in writing, this is a solution offered to young voters.
\end{abstract}

Keywords: Political Education, Youth Voters, Elections, and Participation

\section{INTRODUCTION}

Youth are people aged between 16 and 29 years. This age limit refers to the age limits used by international survey institutions such as The Pew Research Center and Gallup. The number of youth in the year is estimated at around 53 million. If we compare this number with the implementation of elections in Indonesia, this number is equivalent to the number of registered voters who did not exercise their voting rights in the 2009 Legislative Election, which was around 49 million. These statistical figures show how important and significant youth are in determining the direction of national political development [1].

This youth in 2014 is a new generation that has characteristics and characteristics, backgrounds, experiences and challenges that are different from those of the previous generations. Most of them come from students, have good economic status, and generally live in urban areas or surrounding areas. This group is very touched by the advancement of information technology, they use sophisticated technology tools well, ranging from mobile phones, laptops, tablets and various other gadgets. They are also very well versed in the use of facilities and social media networks, such as, twitter, facebook, linked in, and so on. They are very open to learning new, critical and independent things. This youth group certainly faces very difficult challenges, ranging from political changes and domestic problems that have not clearly resolved the direction to the pressures of globalization, free trade, terrorism, international intervention, and so on. Differences in the nature and character, background, experience and challenges of young people today need to be well understood, especially to prepare smart, critical and future-oriented youth. Coupled with the fact that the youth of this youth is the bearer of the leadership at the end of the 100 Years of the Republic of Indonesia in 2045 later. The Republic of Indonesia will still exist (exist) at that time will be very determined by these young people.

The significant influence of youth and a significant number of political party elites in the 2014 Legislative Election yesterday with a lot of time spent campaigning among youth and recruiting youth 
as candidates for political parties. Even the hunt for youth voices has begun since the Regional Head Elections (Pilkada) that have been held for the past two years. Many local elections have begun to take into account the voices of the youth in the campaign process so that it is not uncommon for various methods to be able to gather the voices of these young voters. One thing that must be of particular concern is that political education is still low among young people or can be referred to as the beginner voter [2].

Behind such a significant amount, it turns out that there are other problems related to the level of participation of novice voters. The level of participation using voting rights in several elections of the Governor of North Sumatra in 2008 amounted to 5,089,067, around $60.05 \%$ and in 2013 it decreased to total 5,001,431 or around 48.6\% [3]. Furthermore, Indonesia will be one of the 7 countries with the largest economic growth in the world by 2030, passing through Germany and the United Kingdom, due to the youth population that is maintaining Indonesia's economic productivity. It is estimated that $70 \%$ of Indonesia's population is productive age which ranges between 15-64 years in the next 18 years. Seeing these conditions, it is necessary to take good steps in providing political education to the public.

Holdar and Zakharchenko (2002) refer to political education as public education, namely the effort to involve citizens in a community to create a culture of participation [4]. Youth polititcal education is not a program that can only be implemented prior to the holding of general elections, both legislative elections, presidential and vice-presidential elections and post-conflict local elections. The implementation of political education towards youth is a continuous and continuous activity from time to time.

The political education program is one of the efforts to increase public political participation. Political socialization is divided into two: political education and political indoctrination. Political education is a dialogue process between the giver and the recipient of the message. Through this process the community members recognize and learn the values, norms, and political symbols of their country from various parties in the political system such as schools, government and political parties [5]. This program is not only the responsibility of the government, political parties and other stakeholders, but is the responsibility of all elements of the nation in order to realize a more consolidated democracy in Indonesia.

One of the most active segmentations and has enormous potential is among the youth. This youth political education was intended because of the large number of youth at that age. In addition, in general these young people are still very rarely active politically. The majority of young people are students who are in class III high school / equivalent or who are in undergraduate college. With a pattern of education that is both fun and not boring, it is hoped that these young voters will be able to understand and understand the scope of politics and the benefits of actively participating in politics and getting to know wider politics as a means to reach the welfare of society at large. Responding to the challenges and problems above, it is considered important to know young voter participation in democratic parties or general elections.

Furthermore, young people have often been categorized as a group apart from conventional politics, and this disengagement contributes to the growing sense of belonging even alienation towards politics. The most important thing for young people involved in politics is that they matter to them. Nevertheless, since 2012, there has been a significant change in Indonesia [7].

However, the political representation of young women and men remains limited. They are increasingly demanding more meaningful participation in decision-making processes so they can have more control over how their lives and futures are shaped.To make a difference in the longer term, it is essential that young people are engaged in formal political processes and have a say in formulating today's and tomorrow's politics. Inclusive political participation is not only a fundamental political and democratic right but also is crucial to building stable and peaceful societies and developing policies that respond to the specific needs of younger generations. For young people to be adequately represented in political institutions, processes and decision-making, and in particular in elections, they must know their rights and be given the necessary knowledge and capacity to participate in a meaningful way at all levels [8].

\section{MATERIALS \&MethodS}

\subsection{Research Design}

This research method is a qualitative research method. The model used was adopted from the BRIDGE program (Building Resources In Democracy, Government and Election) which was initiated 
by the UNDP (United Nation for Development Program) by exploring the procedures for the application of political education to be interesting and fun and can be taught continuously. This BRIDGE pattern puts forward the activity of the participants so that they are directly involved in understanding the importance of the concepts theoretically and applied to democracy and political representation

\subsection{Study Samples}

The population is an area of generalization consisting of objects that have certain qualities and characteristics set by drawn researchers and conclusions [9]. The population in this study were students in Public Senior High School 1 Percut Sei Tuan. While the sample representative of the population whose represent results are the overall symptoms observed. The sample in this study were 40 students.

\section{RESULTS \&DISCUSSION}

\subsection{Result}

Political education for young voters in order to increase participation in voting rights in general elections is carried out by providing counseling or lectures and question and answer goes well and smoothly. The meeting began with the provision of material with the activities conveyed about: 1) introduction to young voter political education, 2) providing understanding to the younger generation to give their voting rights for the upcoming elections, evaluating the results of political education for young voters to increase participation rights choose in general elections.

Furthermore, in responding to the field of political education, the response was conducted with a question and answer session. Various questions were enthusiastically asked to be answered by the participants in the question and answer session. Questions for participants are: 1) what is meant by politics, 2) political parties participating in the 2019 general election, 3) what are the stages when registering to get a letter to polling stations, 4) the color of 5 ballot papers in the 2019 election and each color to choose anything. The results of this education will be beneficial for students and schools, then it will add to students' understanding of the importance of young voter political education. Achievement of the objectives of political education for young voters, but the limited time provided results in not all material being conveyed in detail. The results of this activity broadly include several components as follows: 1) Successful targets for the number of participants, 2) achievement of training objectives, 3) achievement of planned material targets and 4) participant's ability in material analysis.

As a whole, political education activities for young voters increase participation in voting rights in general elections can be said to be successful. This success in addition to being measured from the four components above, can also be seen from the satisfaction of participants after participating in the activity. The benefits obtained by students of Public Senior High School 1 Percut in Percut Sei Tuan Subdistrict, Deli Serdang Regency are that political education teaches people in general and beginner voters in particular to be more familiar with the political system that exists in the State of Indonesia and increase the nation's sense of nationalism for the younger generation.

\subsection{Discussion}

Political Education is one of the most important aspects for realizing life both in the community, nation and State increasingly becoming more adept. Education should be used as a basis for forming human beings who are adapting. So that education will become a pattern that must be followed by all components in a country. One of the goals of the State of Indonesia is to want to educate the life of the nation. This very noble goal of the State can be used as a spirit to be able to rise to see education as a process of activities to instill noble values into a person and society.

Education is expected to not only transfer knowledge, but must be more than that, namely habituation and formation of attitudes and good behavior for every human being. The purpose of the life of the state mentioned above will be easier to implement if all existing components can work together to realize. One important community that must be present in the dynamics of the life of the nation and state is the young generation. The younger generation is expected to be able to participate in the life of the State. In this case it is politics. So that the younger generation, especially beginner voters, are expected to have extensive and in-depth knowledge about political education in the life of the nation and state. The term political education in English is often equated with political sucialization. The term political socialization if interpreted literally into Indonesian will mean political socialization. 
Therefore, by using the term political socialization many people synonymize the term political education with the term Political Socialization, because both have almost the same meaning. In other words, political socialization is political education in a narrow sense. According to Ramlan Surbakti, in providing an understanding of political education must be explained first about political socialization. Surbakti (1999: 117) argues that: Political socialization is divided into two: political education and political indoctrination. Political education is a dialogue process between the giver and the recipient of the message. Through this process the community members recognize and learn the values, norms and symbols of the country's political symbols from various parties in the political system such as schools, government and political parties. Based on Surbakti's opinion above, political education is a means of political socialization to its citizens. Political education teaches the public in general and beginner voters in particular to be more familiar with the political system that exists in the State of Indonesia. So that it is expected that the socialization of political education is a means to shape the political attitudes and orientation of political people.

It is through this process of political socialization that community members gain attitudes and orientations towards the political life that takes place in society. Political education is a form of education that is carried out in a planned and intentional manner, both in formal and informal forms that try to teach each individual so that his attitudes and actions can be in accordance with the rules that apply socially. In this case it can be seen that political education does not only study individual attitudes and behavior. But political education tries to link the individual's attitudes and behavior with the stability and existence of the political system. The function of political education is very important because political education increases people's knowledge and understanding of political life which in turn will encourage maximum political awareness in a political system.

Referring to some of the meanings of political education mentioned earlier, political education is a conscious effort carried out between the government and members of the community in a planned, systematic and dialogic manner in order to study and reduce various concepts, symbols, things and norms. political norms from one generation to the next. Political education aims to change and shape a person's behavior in order to suit political goals which can make each individual as a responsible political participant. Political education in a broader sense to form a society order that is in accordance with the political demands that want to be applied.

The level of awareness of the novice voters in students of Public Senior High School 1 Percut is still influenced by habits, or just following along. considering that these new voters are the next generation, especially those in the regions. Therefore the awareness of students is generally still determined by the political education received by these students, especially beginner voters. Meanwhile, the intensity of political education received by the community determines the awareness of the beginner voters to give their voting rights correctly. The means of political education in question are Family, School, Neighborhood, Employment, Mass Media, and Direct Political Contacts. Every individual in the group tries to adjust his opinion with his friends maybe because he wants to be with them. So the association group socializes the members by encouraging or urging them to adjust to the attitudes or behavior adopted by the group. A person may become interested in politics or start following political events because his friends do so. A high school graduate child chooses to enter a college because his friends do so. In this case the action of the child changes his interests and behavior to suit his group as an effort to keep him, accepted by the group members. Besides providing information about political events, the mass media also conveyed directly or indirectly the basic values adopted by the community, certain symbols were conveyed in an emotional context because the controlled media system was a powerful tool in the form of political beliefs. Direct political contacts can change the attitudes and orientation of thinking of each individual or group or about things that are political that bring benefits to the person or group.

Basically all activities will work well, if planned in a systematic, detailed and well-programmed manner. The activities of the people's democratic party which are often called elections will be carried out well if all components can participate in these activities with enthusiasm. One way for the democratic party activities to work properly is the existence of political socialization, namely the stages of activities to be carried out. Political socialization is one form of political education. It is expected that with the political education all components of society that will hold elections or regional elections can work together to create democratic and full conditions with full responsibility. The community component that is expected to be able to actively participate in the democratic party activities is the young generation or the beginner voters. 


\section{CONCLUSION}

Based on the results of the study, the conclusion is the level of awareness of novice voters inPublic Senior High School 1school Percut Sei Tuan is still lacking and the level of voting of novice voters in high school students1 Percut Sei Tuan in general elections, is still largely influenced by the intervention of parents, and teachers who are in their schools choose on one particular candidate pair, also based on the results of the study found that the participation of novice voters is just just going along with it. In addition, the level of awareness of first-time voters in voting in the General Election is still not optimal because it is caused by a lack of understanding of the importance of voting rights in the General Elections, and the lack of direct socialization by candidates or successful teams.

\section{REFERENCES}

[1] Badan Pusat Satatistik Tahun 2010: www.BPS.go.id

[2] Amsori, 2017."Penyuluhan Pendidikan Politik Bagi Pemilih Pemula Guna Meningkatkan Partisipasi Hak Pilih Pada Pemilihan Gubernur DKI Jakarta Tahun 2017”. Journal Of Empowerment, Vol. 1, No. 1

[3] Diah Setiawaty, 2013. Pemilih Pemuda, Sudah Cerdas. Laporan Perkumpulan untuk Pemilu dan Demokrasi (Perludem )

[4] Handoyo, Eko dan Lestari, Puji. 2017. Pendidikan Politik. Yogyakarta: Penerbit Pohon Cahaya

[5] Surbakti, Ramlan. 1999. Memahami Ilmu Politik. Jakarta: PT. Gramedia Widiasarana Indonesia

[6] Suwarma Al Muchtar, 2000. Epistimologi Pendidikan Ilmu Pengetahuan. Bandung: Gelar Pustaka Mandiri

[7] Astuti, 2018. Predicting The Behavior of Young Voters in Elections: A Case Study of Governor Election in Jakarta, Indonesia. Malaysian Journal Of Communication, Vol. 34, No. 4

[8] Ruth Beeckmans and Manuela Matzinger, 2017. Youth Participation in Electoral Processes, Handbook for Electoral Management Bodies. European Commission: United Nations Development Programme

[9] Bungin, 2010, “Metode Penelitian Kuantitatif”. Pranada Media Group: Jakarta

\section{AUTHORS' BIOGRAPHY}

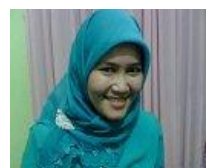

Nina Angelia, M.Si is Lecturer at Faculty of Politics and Social Science, University Of Medan Area, Indonesia.

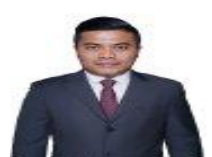

Walid Mustafa Sembiring, M.IP, is a Lecturer at Government Science Study Program, Faculty of Politics and Social Science, University of Medan Area, North Sumatera, Indonesia.

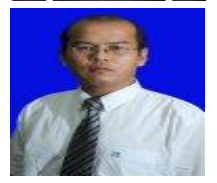

Taufik Wal Hidayat, M.AP, is at Lecturer at Communication Science Study Program, Faculty of Politics and Social Science, University of Medan Area, North Sumatera, Indonesia.

Armansyah Matondang, M.Si, is a Lecturer at Communication Science Study Program, Faculty of Politics and Social Science, University of Medan Area, North Sumatera, Indonesia.

Citation: Nina Anglia, et.al. "Youth Voter Political Education to Increase Rights Participation Choose in General Elections". International Journal of Humanities Social Sciences and Education (IJHSSE), vol. 6, no.7, 2019, pp. 121-125. doi: http://dx.doi.org/10.20431/2349-0381.0607013.

Copyright: () 2019 Authors. This is an open-access article distributed under the terms of the Creative Commons Attribution License, which permits unrestricted use, distribution, and reproduction in any medium, provided the original author and source are credited. 